\title{
Bullying and Peer Acceptance among Adolescents in Selected High Schools in Lusaka District
}

\author{
Tawonga David Bedding*, DR Sidney Mwaba \\ Bullying and Peer Acceptance among Adolescents in Selected High Schools in Lusaka District, Zambia
}

*Corresponding Author: Tawonga David Bedding, Bullying and Peer Acceptance among Adolescents in Selected High Schools in Lusaka District, Zambia

\begin{abstract}
The aim of this study was to investigate the extent to which bullying is related to peer acceptance among adolescents in selected private high schools in Lusaka district. In line with the aim it was hypothesized that there's a significant relationship between bullying/being bullied and peer acceptance in grade nine and ten pupils at two private schools in Lusaka district.

two scales were adopted and used to collect data namely; the Illinois Bullying Scale and the self-perception profile for adolescent social acceptance subscale, measuring bullying and peer acceptance respectively. From a sample of 120 middle adolescents aged 12-17 (77 males and 43 females) randomly selected from two private schools, the researcher selected a non-experimental correlational design before data was analyzed quantitatively in SPSS.

Pearson's correlation was employed for the assumed relationship and lastly, a simple linear regression for the prediction of peer acceptance. The results generated showeda variety of physical and verbal bullying, no significant relationship between bullying and peer acceptance and no significant result to give an accurate prediction. It was concluded that further research must consider other variables and more sensitization needs to be done on the ambiguous nature of bullying.
\end{abstract}

Key words: Bullying, Peer acceptance, Peer rejection, Peer influence, Verbal and Physical Bullying

\section{INTRODUCTION}

The general concept of bullying focuses on intimidation and persecution towards those that are weaker. Farrington, (1993) explains bullying in the context of adolescents as negative actions which may be physical or verbal, have hostile intent, are repeated over time, and involve a power differential and may involve one or more perpetrators and recipients.

World over, bullying of students is becoming more prevalent than ever before. It is also the most common form of aggression and violence in many schools that students engage in. Surveys with students and teachers show that 60 percent of students in Zambia reported being bullied at least once in one month (Jones, Moore, Villar-Marquez and Broadbent, 2008).

Bullying is more likely in classrooms characterized by peer norms that support bullying (Craig and Pepler, 1997; Salmivalli and Karn, 2011), and high peer conflict. Affiliation with aggressive peers is also associated with greater bullying perpetration, (Jones, Moore, Villar-Marquez and Broadbent, 2008) and negative relationships with classmates.

Social interactions among peers in schools often creates an opportunity for them to be accepted as part of the social group. Whether it is on the playground or in the classrooms, adolescents may act aggressively, physically or verbally towards each other. In a number of instances, peer groups tend to accept bullying behavior if it pleases them. Peers may cheer on their fellow colleagues for taunting or name calling other students.

\subsection{Statement of the Problem}

A number of research concerned with bullying has not looked at the relationship that might exist between bullies or those being bullied and peer acceptance. Bullying among adolescents is a major 
concern in Zambia as it has a number of negative repercussions. Peers often accept bullying behavior by cheering on or supporting acts of name calling, taunting or physical aggression. These acts of social acceptance from peers further reinforce the bullying behavior among adolescents.

\subsection{Purpose of the Study}

The findings of this study will be important because they might consequently lead to (a) a policy that allows school authorities to prevent an increase in bullying among adolescents, (b) allowing school authorities and policymakers utilization of results by coming up with appropriate interventions (c) helping policymakers and school authorities to take keen interest in how peers contribute to the levels of bullying in high schools

\subsection{Definition of Terms}

Bullying: negative actions which may be physical or verbal, have hostile intent, are repeated over time, and involve a power differential.

Peer acceptance: the degree to which an adolescent is socially acknowledged by their peers. It is concerned with the level of peer popularity social competency physical attractiveness and cultural traits.

\subsection{Research Question}

1. Is there a relationship between the forms of bullying that exist to the levels of peer acceptance in the selected high school?

\subsection{Hypothesis}

There is a significant relationship between bullying and peer acceptance in Grade nine and ten pupils at two private schools in Lusaka

\section{LITERATURE REVIEW}

Malemesa, (2005) as cited by Salmivalli and Karn, (2011) refer to bullying as physical, verbal and relational. Due to modern technology in communication such as cell-phones cyber bullying has emerged as a new type of bullying. Verbal bullying includes name-calling, threatening, insults and sarcasm whereas relational bullying entails gossiping, hostile gesturing and humiliation. Verbal bullying also involved teasing, mocking and taunting, for example, being called a teacher's 'pet'. Such abusive comments and insults are aimed at making fun, making one unhappy or feeling hurt. This type of bullying is common among girls than boys. Nabuzoka and Smith (1992) conducted a detailed study on bullying and the social relationships of children in schools. One hundred and seventy-nine (179) children were interviewed and asked to describe how they perceived both bullies and victims, from their description, it was possible to identify whether or not bullies were accepted or rejected by their fellow peers. A 'bully' was described as 'someone who often picks on other children, or hits them, or teases them, or does other nasty things to them for no good reason' and a 'victim' as someone who often gets picked on, or hit, or teased, or has nasty things done to them by other children for no good reason. With regard to acceptance and rejection, this study revealed that over half of the pupils $(60 \%)$ reported that they did not think they could join in bullying others. Furthermore, when asked about how they viewed the bullies and the victims about half were upset by itor found it difficult to understand.

Relational bullying mostly occurs when victims are excluded from a group of peers or friends, or isolated in play and work activities. According to Batsche (2007), as cited by Hong and Espelage (2012), relational bullying entails using the personal relationships to harm someone. It is reputational in nature in that it harms someone's social status in class or school. Like physical and verbal bullying types, Malemesa (2005) as cited by Salmivalli and Karn, (2011) argues that relationship bullying includes spreading rumours, ignoring someone, telling and/or passing notes which contain cruel statements about an individual. Other activities are gossiping, intimidating and scaring someone by staring or hiding one's belongings or property. Hong and Espelage, (2012) explain bullying, peer acceptance and rejection with reference to the concept of bystanders, which refers to a viewer, observer, witness or passerby. Bystanders play multiple roles in bullying situations. Bystanders may stand around and watch fights without helping the victim which often encourages the bully, as they 
begin to perceive their actions as being accepted by these bystanders. On the contrary, some bystanders sympathise with the victim and disapprove bullying.

Hong and Espelage, (2012) further highlight the importance of peer relationships and bullying. It can be noted that adolescents seek autonomy from their caregivers and turn to their friends and peers for social support. Thus, it is no surprise that negative peer relationships such as rejection and lack of peer support are significant risk factors for bullying behaviour. Peer acceptance, popularity, and friendships are crucial for many adolescents. Peer acceptance is recognised as a protective factor against peer victimisation, as noted by Demaray and Malecki (2003) who found that youth with low levels of peer acceptance and social support are at increased risk of bullying victimisation. In addition to peer acceptance and social support, the quality of friendship is another major factor; positive friendships can serveas an effective buffer against peer victimisation.

\section{Methodology}

\subsection{Sampling Technique}

The researcher randomly sampled 120 pupils from the population of 200 Grade nine and ten pupils using a lottery method through which individual units where picked up from the whole group by a mechanical process of assigning even and odd numbers. Only the individuals who selected even numbers were picked as part of the sample

\subsection{Participants}

The study sample was 120 students from two private schools. With an age range of 13 to 17 and an average of 14.79. Fifteen year-old pupils were notably the highest frequency accounting for $43.3 \%$ of the total sample. This aided the researcher in achieving the goal of focusing on early and middle adolescents (12 to 17years). The sample included 77 males and 42 females plus one unidentifiable gender.

\subsection{Instruments}

The research employeda checklist formulated from a revised Illinois Bully Scale that was used to identify the bullies and the bullied. A closed-ended questionnaire from a revised self-perception profile for children and adolescents, social acceptance subscale was also used. The Illinois Bully Scale is a research-validated tool that is used to measure bullying through directly surveying students. It works on a scoring system of $(1$ or 2 times $=1,3$ or 4 times $=2,5$ or 6 times $=3,7$ or more times $=$ 4) with the times as an indication of how often bullying occurs.

If an individual indicates 1 or 2 times, they score a 1 on that particular question; if they indicate 3 or 4 times they score a 2 , with the highest score per question indicated as a 4 .

The research also employed. The social acceptance subscale, which measured acceptance among child and adolescent peers. It has a Likert scale of $5=$ strongly agree; $4=$ agree; $3=$ neither agree nor disagree; $2=$ disagree; $1=$ strongly disagree, with individuals that have high average scores indicating high levels of perceived social acceptance. This tool included items such as (1). I am popular with others my age and (2). I have a lot of friends.

The tool contained 6 items. In order to score the subscale items 1, 4 and 6 had to be reversely coded after which an average score was then computed. This average score represented the total social acceptance score per adolescent. A composite score was generated in SPSS to represent the total social acceptance score for all the adolescent pupils and labelled as "TOTALSASS" Total social acceptance subscale.

Both the Illinois Bully Scale and the self-perception scale were tested for reliability with a Cronbach alpha of .773 for the Illinois Bully Scale and .444 for the self-perception profile for adolescents.

\subsection{Data Analysis}

The data was processed quantitatively using SPSS. Descriptive statistics were analyzed on the different forms of physical and verbal bullying indicating the means and standard deviation of the different responses to the questions obtained from the Illinois Bully Scale. 
A Pearson's correlational analysis was done to find out if any significant relationship existed between the composite scores of "total bully" and peer acceptance, and "total bullied" and peer acceptance. Finally, a simple linear regression analysis was also done to identify whether or not the data collected from the bullies and the bullied could be used to predict peer acceptance.

\section{ETHICAL CONSIDERATION}

Ethical clearance was granted by the University of Zambia through the ethics committee after reviewing the paper, Furthermore the research was also approved by the Ministry of Education. The researcher asked for permission from the participants before they were included in the study. The heads of both institutions were informed of the purpose of the study and they gave permission for the study to be conducted in their schools.

\section{FINDINGS AND DISCUSSION}

\section{Forms of Bullying and Levels of Peer Acceptance}

Table1. Means and Standard Deviations of the Form of Bullying

\begin{tabular}{|c|c|c|c|c|}
\hline \multicolumn{2}{|c|}{ PHYSICAL BULLYING } & $\mathrm{N}$ & $\mathrm{M}$ & SD \\
\hline 1. & I helped harass other students & 120 & 0.17 & 0.540 \\
\hline 2. & I physically threatened to hurt or hit another student & 120 & 0.59 & 1.104 \\
\hline 3. & I encouraged people to fight & 120 & 0.56 & 1.083 \\
\hline 4. & I got hit and pushed by other students & 120 & 0.54 & 0.986 \\
\hline 5. & I was physically threatened by other students & 120 & 0.50 & 0.953 \\
\hline \multicolumn{5}{|c|}{ VERBAL BULLYING } \\
\hline 1. & I upset other students for the fun of it & 120 & 1.05 & 1.401 \\
\hline 2. & In a group, I teased other students & 120 & 1.00 & 1.200 \\
\hline 3. & I spread rumors about others & 120 & 0.39 & 0.940 \\
\hline 4. & Other students called me names & 120 & 1.29 & 1.362 \\
\hline 5. & Students spread rumors or told lies about me & 120 & 1.13 & 1.347 \\
\hline
\end{tabular}

*note: Bold represents the "bullies" and those not in bold the "bullied"

a table was generated indicating the different forms of bullying and the specific types acquired from the bully Illinois scale. Statistical data indicating the means and standard deviations of the responses from the questions obtained from the Illinois Bully Scale was also shown in the table.

Malemesa (2005) highlights how bullying subjects' students to physical, social and psychological suffering, and identifies different types and forms of bullying among students such as name calling, group isolation and physical and aggressive behavior. Using descriptive statistics this objective was analyzed through means and standard deviations. Table 1 had the highest average score for bullies indicated as 0.56 from the total sample of $(n=120)$ pupils, reflective of a number claiming they had physically threatened to hurt or hit another student. Malemesa, (2005) a cited by salmivalli and Karn, (2011) refer to bullying as being physical causing one to be unhappy or feeling hurt.

Table 1 further indicates the overall average score of 1.29 reflecting the verbally bullied pupils claiming the other students called them names Malemesa, (2005) as cited by Salmivalli and Karn, (2011) states that due to modern technology in communication such as cell-phones and the internet cyber bullying has emerged as a new type of bullying including forms such as name calling, spreading rumors, gossiping and telling lies.

Table2. Correlation between Bullies/Bullied and Peer Acceptance

\begin{tabular}{|l|l|l|}
\hline Total bully & Total bully & Total sass \\
\hline Person's correlation & 1 & 0.103 \\
\hline Sig (2 tailed) & & 0.265 \\
\hline N & 120 & \\
\hline Total bullied & Total bullied & Total sass \\
\hline Pearson's correlation & 1 & -0.122 \\
\hline Sig (2 tailed) & & 0.183 \\
\hline N & 120 & \\
\hline
\end{tabular}

This study was further analyzed using Pearson's correlation to identify any significant relationship between bullying and peer acceptance. The correlation analysis reflected a weak positive correlation for bullies and a weak negative correlation for the bullied with both cases having significant values 
greater than 0.05 which meant, no significant relationship existed between the bullies, the bullied and peer acceptance.

Table3.0. Model Summary

\begin{tabular}{|l|l|l|l|l|}
\hline Model & R & R Square & Adjusted R Square & Std.error of the Estimate \\
\hline 1 & .194 & .037 & .021 & .51333 \\
\hline
\end{tabular}

Predictors: (Constant), Total Bullies, Total Bullied

Table3.1. Anova

\begin{tabular}{|l|l|l|l|l|l|}
\hline Model & Sum of Squares & DF & Mean Square & F & Sig \\
\hline Regression & 1.201 & 2 & .600 & 2.279 & .107 \\
Residual & 30.830 & 117 & .246 & & \\
Total & 32.031 & 119 & & & \\
& & & & & \\
\hline
\end{tabular}

Predictors: (Constant), Total Bullies, Total Bullied

Dependent Variable: Total social acceptance sub scale

Table3.2. Coefficients

Unstandardized Coefficients Standardized Coefficients

\begin{tabular}{|l|l|l|l|l|l|}
\hline Model & B & Std. Error & B & T & Sig \\
\hline Constant & 3.196 & .080 & & 39.727 & .000 \\
Total Bullies & .014 & .008 & .159 & 1.655 & .101 \\
Total Bullied & -021 & .011 & -.173 & -1.811 & .073 \\
\hline
\end{tabular}

Dependent Variable: Total social acceptance subscale

With the aim of the research centered on investigating if there was a relationship between bullying and peer acceptance, a simple linear regression analysis was done to analyze this. From the data presented, Table 3.0 showed a model summary with an $\mathrm{R}^{\wedge} 2$ (R-squared) of 0.037 translated to 3.7 per cent accounting for the variation in the peer acceptance influenced by the bullies or the bullied. With 96.3 per cent of the variation as a result of other factors it is difficult to accurately predict the level of peer acceptance related to the level of bullying.

Table 3.1 further indicates a significant value related to the F-ratio of 0.107 , which is greater than 0.05 reflecting no statistically significant level of prediction between the independent variable bullying, on peer acceptance. In addition, Table 3.2 had an unstandardized coefficient value for bullies of 0.14 , meaning for each unit of increase of the bullies, a pupil would get an increase of 0.014. Furthermore, in the case of the pupils being bullied for each unit of decrease, a pupil would get a decrease of 0.021 . For both cases, the significant values were greater than 0.05 meaning no statistically significant data was made available to give an accurate prediction of peer acceptance based on bullying.

\section{CONCLUSION AND RECOMMENDATIONS}

The study showed that there were to be no significant relationship between bullying and peer acceptance. The study further showed that bullying is an ambiguous concept existing in a number of physical and verbal forms. In view of the findings, this study recommends that.

1. Bullying is an ambiguous concept, as such, policymakers should ensure that they put measures in place that will help sensitize pupils on the different forms of bullying.

2. Institutions of learning especially in secondary schools need to educate their students on how to tackle bullying with the aim of improving their self-esteem.

3. Further studies should consider larger sample sizes with a wider variety of adolescent groups using reliable standardized and localized tools of measurement.

\section{REFERENCES}

[1] Besag, V. (1989). Bullies and Victims in Schools. Philadelphia, PA: Open University Press.

[2] Buhs, E.S., and Ladd, G.W. (2001). Peer Rejection as an Antecedent of Young Children's School Adjustment: An Examination of Mediating Processes. Developmental Psychology, 37, 550-560. 
[3] Cairns, R. and Cairns, B. (1991). Social Cognition and Social Networks: A Developmental Perspective in the Development and Treatment of Childhood Aggression, Pepler, D., and Rubin, K. (Eds). Hillsdale, NJ: L. Erlbaum, pp. 249-278.

[4] Craig, W. and Pepler, D. (1997). "Observations of Bullying and Victimization in the Schoolyard." Canadian Journal of School Psychology, 2, $41 \pm 60$.

[5] Demaray, S., and Malecki, J. (2003). "Proximate Causes of Aggressive Fighting in Middle School Children." British Journal of Educational Psychology, 63, 231-244.

[6] Farrington, D. (1993). Understanding and Preventing Bullying. In Crime and Justice, Tonrey, M. (Ed.). Chicago: University of Chicago Press.

[7] Hong, S., J and Espelage, L.D. (2012) Review of Research on Bullying and Peer Victimization In Schools: An Ecological System Analysis. Aggression and Violent Behavior, 17, 311-322

[8] Jones, N., Moore, K., Villar-Marquez, E. and Broadbent, E. (2008, October). 'Painful Lessons: The Politics of Preventing Sexual Violence and Bullying at School-Working Paper 295.' London: Overseas Development Institute and Plan International.

[9] Nabuzoka, D., and Smith, P.K. (1993). Sociometric Status and Social Behaviour of Children with and without Learning Difficulties. Journal of Child Psychological and Psychiatry,43, 1435 - 1448.57.

[10] Salmivalli, C., Karna, A. and Poskiparta E. (2011). "Counteracting Bullying in Finland: The Kiva Program and Its Effects on Different Forms of Being Bullied.” International Journal of Behavioural Development 35 (5) 405-411.

\section{AUTHORS' BIOGRAPHY}

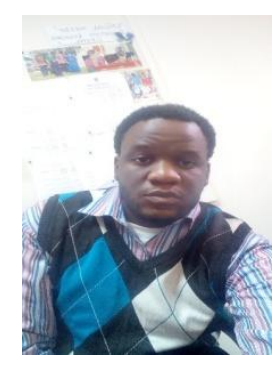

Tawonga David Bedding, is a post graduate degree (masters) student in the field of child and adolescent psychology his dissertation focused on Bullying and peer acceptance among adolescents in Lusaka Zambia

He has lectured for 3years in the field of Psychology, Sociology and Communication skills, he also has a keen interest in Child literacy development and the use of Visual aid in child Education.

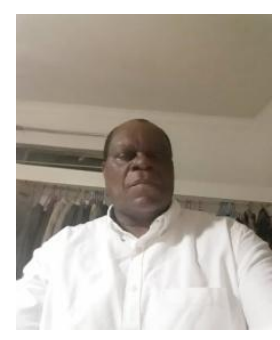

DR Sidney OC Mwaba, is a senior Lecturer in the Department of Psychology at the University of Zambia. He has been teaching for over 30years and has published in fields of family relations, sexual and reproductive health as well as factors affecting Academic Performance.

Citation: Tawonga David Bedding. "Bullying and Peer Acceptance among Adolescents in Selected High Schools in Lusaka District" International Journal of Humanities Social Sciences and Education (IJHSSE), vol 7, no. 6, 2020, pp. 110-115. doi: http://dx.doi.org/10.20431/2349-0381.0706012.

Copyright: (1) 2020 Authors. This is an open-access article distributed under the terms of the Creative Commons Attribution License, which permits unrestricted use, distribution, and reproduction in any medium, provided the original author and source are credited. 